\title{
Study of the Behavior of Gold and Accompanying Chemical Elements in Weathering Profile on a Quartz Vein in Mintom (South Cameroon, Central Africa)
}

\author{
Aurélien Manfred Mbenoun ${ }^{1}$, Gilbert François Ngon Ngon ${ }^{1}$, Michel Bertrand Mbog $^{3}$, Rose Yongeu Fouateu ${ }^{2} \&$ Paul \\ Bilong ${ }^{2}$ \\ ${ }^{1}$ Laboratory of Geosciences, Natural Resources and Environment, Department of Earth Sciences, Faculty of Sciences, \\ University of Douala, B.P: 24157, Douala, Cameroon \\ ${ }^{2}$ School of Geology and Mining, University of Ngaoundéré, B.P 96, Ngaoundéré, Cameroon \\ ${ }^{3}$ Department of Earth Sciences, University of Dschang, B.P 67, Dschang, Cameroon \\ Correspondence: Michel Bertrand Mbog, Department of Earth Sciences, University of Dschang, B.P 67, Dschang, \\ Cameroon. E-mail: michelbertrandmbog@yahoo.fr
}

Received: June 1, 2021

doi:10.5539/esr.v10n2p54

\author{
Accepted: July 5, $2021 \quad$ Online Published: July 28, 2021 \\ URL: https://doi.org/10.5539/esr.v10n2p54
}

\begin{abstract}
The present study, which focuses on the behavior of gold and its accompanying chemical elements developed on an alteration profile, is carried out in a humid equatorial zone at Mintom in South Cameroon (Central Africa). The methodology used to achieve the results obtained focused on the description of the morphology of the outcrop, the petrography of the rock studied, the study of heavy minerals accompanying gold in the weathering materials on smear slides, mineralogical analysis of weathering materials by X-ray diffraction (XRD), scanning electron microscopy (SEM) analysis of gold and geochemical analyzes by ICP - AES and ICP - MS of weathering materials. The main results obtained from this methodology inform us that on the petrographic level the main rock studied is the gold-bearing quartz vein located in Zom, consisting mainly of quartz and opaque minerals. Morphologically, the weathering materials developed on this granite basement present an advanced $\mathrm{ABC}$-type profile characterized by a significant thickness (4 to $6 \mathrm{~m}$ ). The morphological and chemical characters of the gold particles have evolved from the mineralized zone to the surface. This development was marked by an increase in blunt, rounded grains. Morphoscopy and scanning electron microscopy of the gold particles have shown hollow, blunt to sub-blunt grains, non-evolved free particles, and evolved free particles, respectively. In most samples of weathered material gold is found in association with chemical elements such as $\mathrm{Ag}, \mathrm{Cr}$, $\mathrm{Co}, \mathrm{Cu}, \mathrm{Ni}, \mathrm{V}$ and figure 10 show identical behavior between these chemical elements and gold, but particularly between silver and gold, which would testify to an identical origin. Au concentrations are very high in most samples of weathering material. Also, these samples of altered materials with a high proportion of gold (0.01 to $2.28 \mathrm{ppm})$ also present high concentrations of silver (Ag) which justifies that the occurrence or the gold deposit is associated with silver and can be exploited as a geochemical parameter to prospect for gold in the study area.
\end{abstract}

Keywords: Equatorial Zone, Gold, Granitic basement, Mintom, Quartz vein, Weathering

\section{Introduction}

The vertical distribution of gold and its mobility in surface and sub-surface environments associated with weathering processes have been well studied by many authors in recent decades (Baker, 1978; Mann, 1984; Webster et Mann, 1984; Andrade et al., 1991; Benedetti and Boulègue, 1991; Bowell et al., 1993a, 1993b; Colin et al., 1993; Leybourne et al., 2000; Aleksandrov, 2007; Myagkaya et al., 2016a, 2016b). However, large tropical areas are largely covered by a thick mantle of lateritic weathering (Andrade et al., 1991; Colin and Vieillard, 1991; Leybourne et al., 2000; Dold and Fontboté, 2002; Al et al., 2006; Mbenoun et al., 2013; Myagkaya et al., 2013; Myagkaya et al., 2016a, 2016b; Tehna et al., 2019) developed on various rocks and a small part of which could be gold bearing. The behavior of gold, its mobility and its distribution in this landscape have been sufficiently studied (Edou-Minko, 1989; Freyssinet et al, 1989b; Colin \& Vieillard, 1991; Edou-Minko et al., 1992; Colin, 1992; Colin et al., 1993; Mbenoun et al., 2013).

The morphology, mineralogy and geochemistry of gold particles have been also studied (Stoffregen, 1986; Freyssinet et al., 1989; Colin and Vieillard, 1991; Bowell, 1992; Colin et al., 1997; Oliveira and Oliveira, 2000; Kalinin et al., 2009; Hough et al., 2011; Fairbrother et al., 2012; Yesares et al., 2015; Shuster et al., 2016). In addition, gold mobility occurs 
through very short-distance transfers or occurs in situ in weathering patterns (Stoffregen, 1986; Bowell, 1992; Bowell et al., 1993b; Varajão et al., 2000). Therefore, Varajão et al. (2000) showed that the distributions of gold grades of weathered rocks are controlled by hydrothermal distribution processes. However, the behavior of gold and its accompanying elements vary according to geological, geomorphological and bioclimatic contexts. The objective of this study relates to the behavior of gold and its accompanying chemical elements in a weathering profile on a quartz vein at Mintom (Cameroon, Central Africa).

\section{Geographical and Geological Setting}

The study area is located in South-Cameroon, in the Dja and Lobo department, in the Dja valley, in the middle of the equatorial forest. Its geographic coordinates are $02^{\circ} 30^{\prime \prime}$ and $02^{\circ} 45^{\prime \prime}$ North Latitude and $13^{\circ} 15^{\prime \prime}$ and $13^{\circ} 30^{\prime \prime}$ East Longitude (Figure 1). The region has a sub-equatorial climate (Suchel, 1972). The study area is a large area extending from the Atlantic coast in the west to the Congo Basin in the east. It is essentially made up of pyroxene and biotite granites, biotite and amphibole granites, pink granite, charnockites, migmatites and quartz veins (Figure 2). These geological formations belong to the Congo Craton, made up of crystalline rocks of Archean and Neo-Proterozoic crystallophyllian ages and sedimentary Precambrian formations of the upper Dja series (carbonate rocks and pelites) (Vidal, 1933). Vidal (1933) showed that these lithological formations are fractured and marked by a tectono-metamorphic evolution.

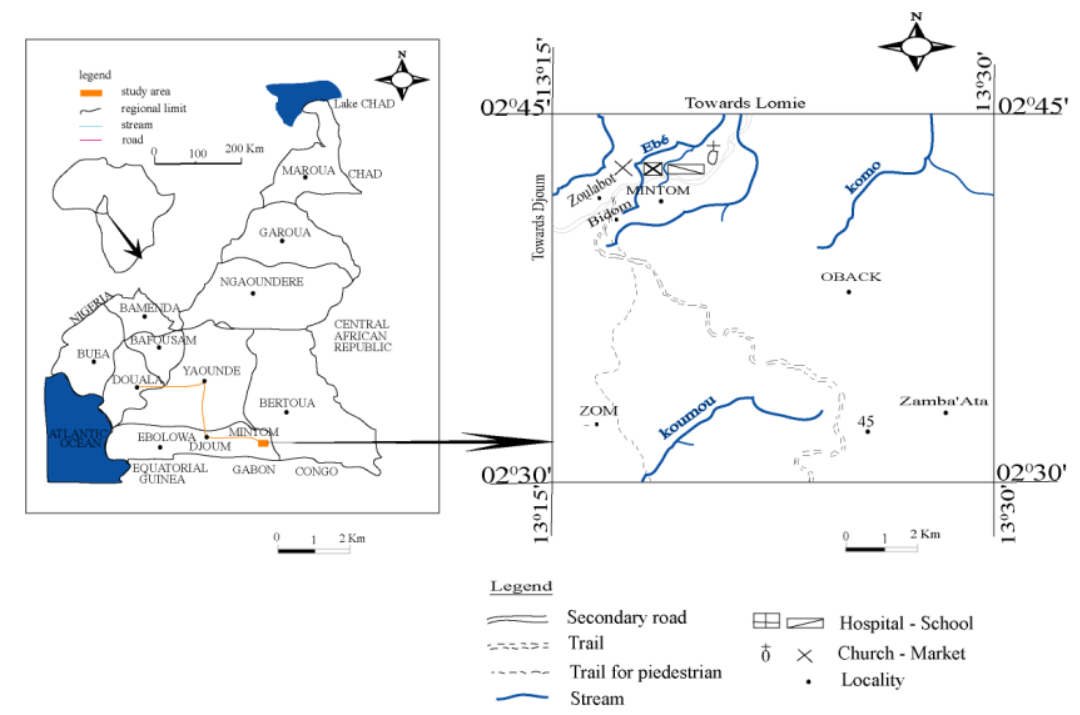

Figure 1. Location of study area

\section{Materials and Methods}

A study was carried out in the Zom gold zone located about $17 \mathrm{~km}$ from the town of Mintom. This area was highlighted by a craft activity. Thus, a representative profile located on the upper slope of an interfluve can be observed by digging a well in the alteration materials developed on a vein of gold-bearing quartz. The observation of gold-bearing quartz veins was carried out following systematic prospecting carried out in the study area by following the network of quartz veins along the valley to the slopes of the hill. The horizons of this profile have been differentiated according to their color (using the Munsell Code), their texture, their thickness and the elements represented. In total, six samples were taken from this profile, including the underlying bedrock which is a quartz vein. Several analyzes were carried out on these samples, in this case the mineralogical and chemical analyzes. The materials from each horizon were breaded to determine the mineralogy of heavy minerals present in the sand fraction. Heavy minerals present were identified using the Duplex technique (1958) and gold grains were manually selected. 


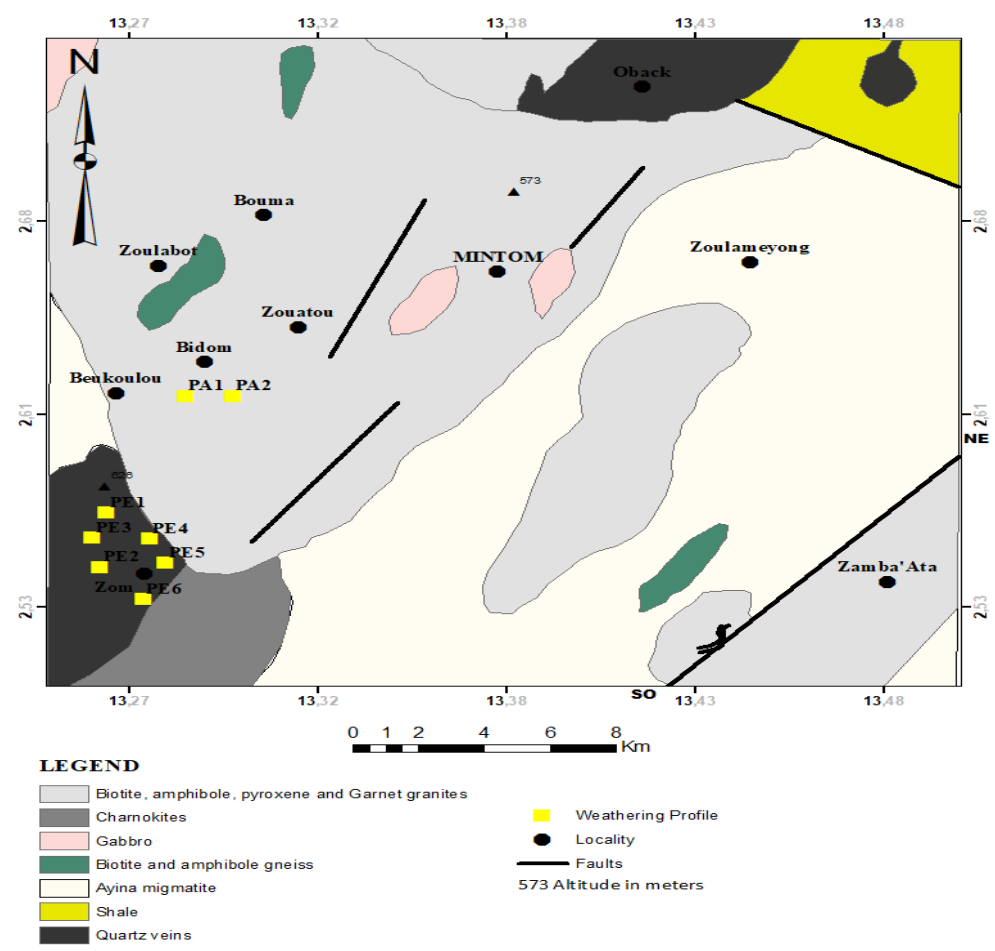

Figure 2. Geological map of the study area (after Gazel et al., 1956; modified)

On altered materials, mineralogical surveys were carried out at the Research Institute for the Development (IRD), France, on bulk samples using a Brüker D8 ADVANCE diffractometer with a copper source $(1=1.5489 \mathrm{~A})$ at $40 \mathrm{kV}$ and $30 \mathrm{~mA}$. The exposure time for the qualitative analysis was 2 hours. The samples were sprayed in an agate mortar; the resulting powder was taken from a piece of tape before being irradiated with $\mathrm{Cu} \mathrm{K} \alpha$ radiation in the diffractometer. The resulting diffraction spectra were compared to a computerized database of common minerals, and the automatic mineral pairing function was aided by the operator's identification of phases consistent with the known compositions of the materials. The phase proportions were estimated by the peak matching program without calibration on synthetic mixtures of known phase proportions. The geochemical analyzes were carried out at the ALS Chemex laboratories in Pretoria, South Africa. The homogenized powder from these sample batches was dissolved by an acidic digestion procedure with $\mathrm{HF}^{\mathrm{HNO}} \mathrm{H}_{3}$ and $\mathrm{HClO}_{4}$, then chemically analyzed for major elements by inductive plasma atomic emission (ICP-AES). The trace elements were analyzed by inductive plasma mass spectrometry (ICP-MS). In fact, the same mixed acid ( $\mathrm{HF}+\mathrm{HNO}_{3}+$ $\mathrm{HClO}_{4}$ ) at $200{ }^{\circ} \mathrm{C}$ under pressure was used and the dissolved solution obtained was measured on a Perkin Elmer Elan 9000 type instrument. Corrected using an internal indium standard. The precision for trace elements is better than 5\% (Burnham and Schweyer, 2004). The detection limits for major elements and trace elements were respectively set at $0.01 \%$ by weight and $0.5 \mathrm{ppm}$. Electron Microprobe Analysis (EMPA) was performed on polished gold grains using a CAMECA SX100 at SGS Laboratories in Johannesburg, South Africa. The chemical composition of the gold inclusions was obtained by wavelength dispersion spectrometry (WDS) using a JEOL SUPERPROBE 8200. The polished sections were coated with carbon before microprobe analysis.

\section{Results and Discussions}

\subsection{Description of the Weathering Profile Studied (PE)}

The studied gold profile has geographic coordinates of N02 30 " 14 " and E13 ${ }^{0} 19^{\prime \prime} 59$ " with a thickness of approximately 3.45 meters above the quartz vein bedrock (Figure 3 ). This profile resulting from the alteration of the underlying bedrock presents three main groups including: the saprolite, the glebular group and the clay-sandy group. The morphology of this profile is similar to that described in the weathering layers of the African equatorial zone (Bocquier et al., 1984; Tardy, 1993). From bottom to top, we observe:

The quartz vein: it is compact. It is composed of millimeter to centimeter angular quartz alternating with light dark ferromagnesian beds (Figure 3A); (1) the underlying coarse saprolite and fine saprolite. The coarse saprolite layer (10-30 $\mathrm{cm}$ thick) has retained the structure of the parent rock and is made up of primary minerals including blocks of quartz and accessory minerals (epidote, zircon, tourmaline, andalusite, beryl, topaz, hypersthene, hornblende, garnet, rutile, apatite, 
anatase and opaque oxides). It is embedded in a gray-brown clay-sandy matrix (5YR8/4) which consists of kaolinite and smectite. We notice here the presence of goethite and hematite. Coarse saprolite gradually transforms into fine saprolite corresponding to a thin $(20 \mathrm{~cm})$ gravelly and mottled clay layer where the relics of quartz fragments and accessory minerals remain in an abundant reddish clay matrix (5YR6/4) composed of kaolinite and goethite, and with whitish spots or yellow and dark bands. This layer is surmounted by a red (5YR 6/4) or reddish brown (10YR 2/2) centimetric gravelly layer enriched with quartz and accessory minerals (epidote, zircon and tourmaline, or rutile and opaque oxides) embedded in a matrix of sandy clay consisting of kaolinite, goethite, hematite and more or less smectite; (2) the nodular unit (40-80 $\mathrm{cm})$ consists of millimetric to decimetric ferruginous nodules of hematite and goethite. The nodules as well as many corroded quartz centimeter to decimetric are embedded in a dark red clayey-sandy matrix (5YR 6/4); (3) the clay-sandy complex has a thickness ranging from 15 to 40 centimeters. The ferruginous nodules gradually disappear in favor of the yellowish clayey-sandy matrix (5YR 5/6) made up of kaolinite + goethite + hematite. This set is covered by a humus horizon. The weathering materials developed on the gold-bearing quartz vein at the level of the upper slope of the interfluve have been observed in different bioclimatic zones (Edou Minko, 1989; Freyssinet et al., 1989a; Colin and Vieillard, 1991; Edou Minko et al., 1992; Colin, 1992; Bowell et al., 1993; Colin et al., 1993; Mann, 1984; Smith and Keele, 1984; Freyssinet et al., 1989b; Sanfo et al., 1992; Freyssinet, 1993; Ouangrawa et al., 1996; Akwinga, 2010). Likewise, the significant presence of kaolinite and relatively smectite in these weathered materials indicates the presence of the monosiallitization and bisiallitization processes undergone by the source rocks. In addition, the presence of primary minerals such as epidote, zircon, tourmaline, amphibole, rutile, andalusite, beryl, topaz, apatite, hypersthene and garnet in saprolite symptomatically determines the both magmatic and metamorphic nature of the Congo craton (Toteu et al., 2004; 2006) with the establishment of mineralization by hydrothermal processes.

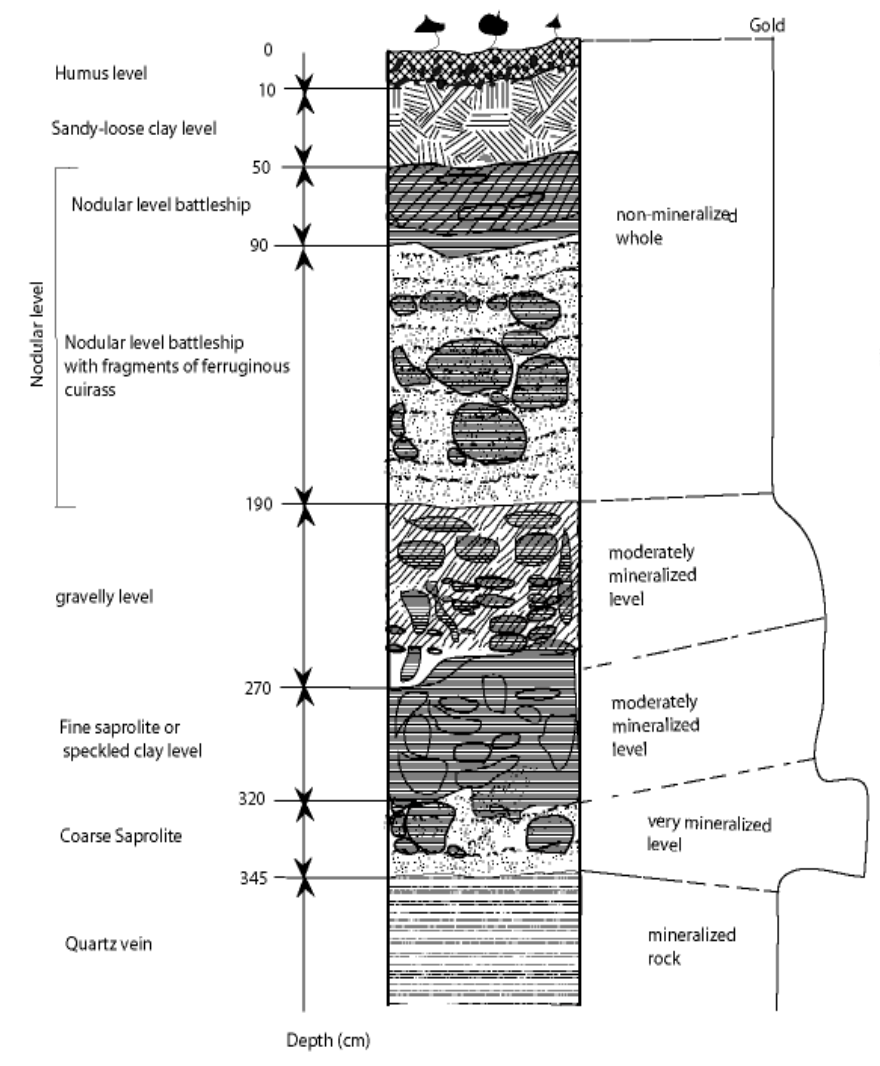

(A)
(B)

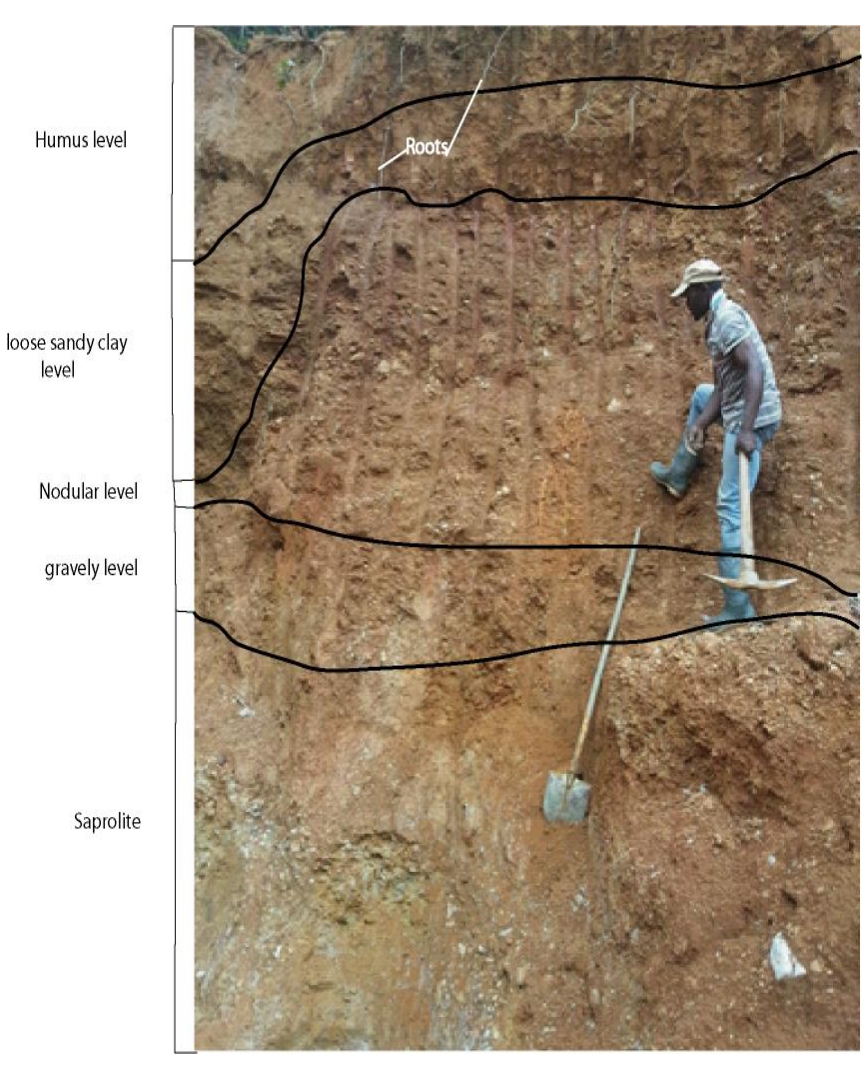

(C)

Figure 3. Zom (PE) weathering profile (A); evolution of gold mineralization (gold grains) in the profile (B); well made at the top of the slope $(\mathrm{C})$

\subsection{The Quartz Vein}

\subsubsection{Quartz Vein Petrography}

Macroscopic observation of the quartz vein taken from the base of the PE profile at Zom shows that it's massive and has a 
yellowish-gray color (beginning of alteration). The minerals in this rock are mainly quartz and opaque minerals directly observable with the naked eye (Figure 4A). Microscopic study shows that it has a grainy texture with a heterogranular tendency. It consists of quartz and opaque minerals (Figure 4B).

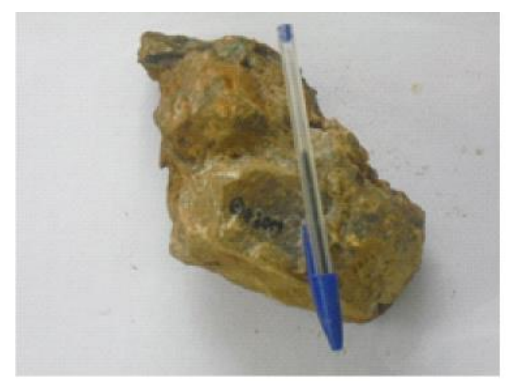

(A)

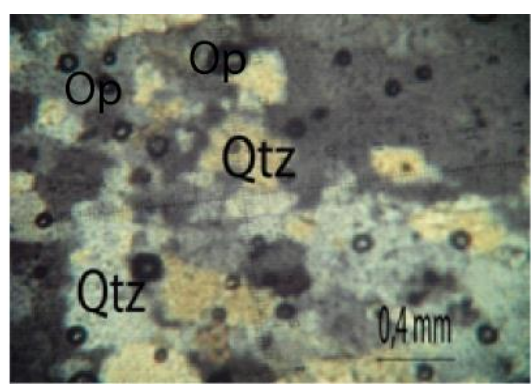

(B)

Figure 4. Zom quartz vein sample (A); Zom quartz vein observed in LPA (B). Qtz: quartz; Op: Opaque minerals

\subsubsection{Quartz Vein Geochemistry}

\subsubsection{The Major Elements}

The quartz vein $(\mathrm{Z1})$ is characterized by very high contents of $\mathrm{SiO}_{2}(90.50 \%)$, moderate to low of $\mathrm{Al}_{2} \mathrm{O}_{3}(5.89 \%)$ and $\mathrm{Fe}_{2} \mathrm{O}_{3}(2 \%)$, and low contents of less than $1 \%$ in oxides such as $\mathrm{TiO}_{2}, \mathrm{MnO}, \mathrm{MgO}, \mathrm{Na}_{2} \mathrm{O}, \mathrm{CaO}, \mathrm{K}_{2} \mathrm{O}, \mathrm{Cr}_{2} \mathrm{O}_{3}$ and $\mathrm{P}_{2} \mathrm{O}_{5}$ (Table 1).

Table 1. Concentrations of major elements in \% of the materials of the Zom PE profile

LOI : Loss On Ignition; CIA : Chemical Index of Alteration.

\begin{tabular}{|c|c|c|c|c|c|c|}
\hline \multirow{2}{*}{$\begin{array}{l}\text { Profile } \\
\text { Level } \\
\text { Colors }\end{array}$} & \multicolumn{6}{|c|}{$\mathrm{PE}$} \\
\hline & $\begin{array}{l}\text { Quartz } \\
\text { vein } \\
\text { grey } \\
\end{array}$ & $\begin{array}{c}\text { Coarse } \\
\text { Saprolite } \\
\text { grey }\end{array}$ & $\begin{array}{c}\text { Fine } \\
\text { saprolite } \\
\text { red }\end{array}$ & $\begin{array}{c}\text { Gravelly } \\
\text { level } \\
\text { red }\end{array}$ & $\begin{array}{l}\text { Nodular } \\
\text { level } \\
\text { red }\end{array}$ & $\begin{array}{l}\text { Clay } \\
\text { level } \\
\text { red }\end{array}$ \\
\hline Depth (m) & & 0,25 & 0,5 & 0,8 & 1 & 1 \\
\hline Samples(\%) & $\mathbf{Z 1}$ & $\mathbf{Z 2}$ & $\mathbf{Z 3}$ & $\mathbf{Z 4}$ & $\mathbf{Z 5}$ & Z6 \\
\hline $\mathrm{SiO}_{2}$ & 90,50 & 75,7 & 61,80 & 72,60 & 52,9 & 66,70 \\
\hline $\mathrm{TiO}_{2}$ & 0,46 & 0,22 & 1,13 & 1,27 & 0,41 & 1,02 \\
\hline $\mathrm{Al}_{2} \mathrm{O}_{3}$ & 5,89 & 3,78 & 18,25 & 14,15 & 8,83 & 17,55 \\
\hline $\mathrm{Fe}_{2} \mathrm{O}_{3}$ & 2,00 & 9,02 & 9,92 & 5,78 & 29,9 & 7,00 \\
\hline $\mathrm{MnO}$ & 0,01 & 0,02 & 0,03 & 0,02 & 0,04 & 0,02 \\
\hline $\mathrm{MgO}$ & 0,02 & 0,01 & 0,06 & 0,06 & 0,04 & 0,07 \\
\hline $\mathrm{CaO}$ & 0,01 & 0,01 & 0,01 & 0,01 & 0,02 & 0,02 \\
\hline $\mathrm{Na}_{2} \mathrm{O}$ & 0,03 & 0,01 & 0,01 & 0,01 & 0,01 & 0,01 \\
\hline $\mathrm{K}_{2} \mathrm{O}$ & 0,01 & 0,01 & 0,19 & 0,21 & 0,01 & 0,03 \\
\hline $\mathrm{P}_{2} \mathrm{O}_{5}$ & 0,01 & 0,71 & 0,07 & 0,04 & 0,16 & 0,05 \\
\hline $\mathrm{Cr}_{2} \mathrm{O}_{3}$ & 0,027 & 0,15 & 0,03 & 0,032 & 0,22 & 0,09 \\
\hline LOI & 2,51 & 11,7 & 9,62 & 6,58 & 7,30 & 8,03 \\
\hline Total & 101,47 & 101,34 & 101,12 & 100,76 & 99,84 & 100,59 \\
\hline $\mathrm{SiO}_{2} / \mathrm{Al}_{2} \mathrm{O}_{3}$ & 15,36 & 2,39 & 3,39 & 5,13 & 5,99 & 3,80 \\
\hline $\mathrm{Fe}_{2} \mathrm{O}_{3} / \mathrm{K}_{2} \mathrm{O}$ & 200,00 & 7570,00 & 52,21 & 27,52 & 2990,00 & 233,33 \\
\hline $\mathrm{Al}_{2} \mathrm{O}_{3} / \mathrm{TiO}_{2}$ & 12,80 & 17,18 & 16,15 & 11,14 & 21,53 & 17,21 \\
\hline $\mathrm{K}_{2} \mathrm{O} / \mathrm{Na}_{2} \mathrm{O}$ & 1,00 & 1,00 & 19,00 & 21,00 & 1,00 & 3,00 \\
\hline CIA & 99,15 & 99,21 & 98,86 & 98,40 & 99,55 & 99,66 \\
\hline$\left(\mathrm{Na}_{2} \mathrm{O}+\mathrm{K}_{2} \mathrm{O}\right) / \mathrm{Al}_{2} \mathrm{O}_{3}$ & 0,003 & 0,005 & 0,01 & 0,01 & 0,002 & 0,002 \\
\hline
\end{tabular}




\subsubsection{Trace Elements}

The trace element contents of the quartz vein are characterized by high concentrations in Transition Trace Element (TTE) greater than $100 \mathrm{ppm}(\mathrm{Cr}$ and V). This quartz vein is also characterized by high Field Strength Element (HFSE) contents greater than $10 \mathrm{ppm}$, in particular $\mathrm{Zr}$ and $\mathrm{Y}$. Furthermore, U, Th, Hf, $\mathrm{Nb}$ and Ta have low concentrations of less than $2 \mathrm{ppm}$. The Ba of the Large Ion Lithophile Element (LILE) group shows a concentration greater than $10 \mathrm{ppm}$, while the other LILEs have concentrations less than 1 ppm (Table 2)

Table 2. Concentration of trace elements in ppm of Zom PE profile.

\begin{tabular}{|c|c|c|c|c|c|c|}
\hline \multirow{2}{*}{$\begin{array}{l}\text { Profile } \\
\text { Level }\end{array}$} & \multicolumn{6}{|c|}{$\mathrm{PE}$} \\
\hline & $\begin{array}{l}\text { Quartz } \\
\text { vein }\end{array}$ & $\begin{array}{l}\text { Coarse } \\
\text { saprolite }\end{array}$ & $\begin{array}{l}\text { Fine } \\
\text { saprolite }\end{array}$ & $\begin{array}{c}\text { Gravelly } \\
\text { level }\end{array}$ & $\begin{array}{l}\text { Nodular } \\
\text { level }\end{array}$ & $\begin{array}{l}\text { Clay } \\
\text { level }\end{array}$ \\
\hline Colors & grey & grey & red & red & red & red \\
\hline Depth (m) & & 0,25 & 0,5 & 0,8 & 1 & 1 \\
\hline Samples & & & & & & \\
\hline (ppm) & $\mathrm{Z1}$ & $\mathbf{Z 2}$ & $\mathbf{Z 3}$ & $\mathbf{Z 4}$ & $\mathbf{Z 5}$ & $\mathrm{Z6}$ \\
\hline $\mathrm{Ba}$ & 12,90 & 12,70 & 70,90 & 91,00 & 19,40 & 35,00 \\
\hline $\mathrm{Rb}$ & 0,50 & 1,10 & 14,90 & 16,20 & 1,10 & 2,80 \\
\hline $\mathrm{Sr}$ & 0,70 & 3,00 & 9,90 & 9,90 & 8,30 & 12,40 \\
\hline $\mathrm{U}$ & 1,50 & 0,38 & 3,26 & 3,14 & 2,52 & 1,45 \\
\hline Th & 0,42 & 1,98 & 15,40 & 15,55 & 5,23 & 7,28 \\
\hline $\mathrm{Zr}$ & 22,00 & 144,0 & 512,00 & 745,00 & 70,00 & 190,00 \\
\hline $\mathrm{Hf}$ & 0,50 & 3,60 & 11,70 & 17,50 & 1,80 & 4,70 \\
\hline $\mathrm{Nb}$ & 1,10 & 3,20 & 20,60 & 22,60 & 3,20 & 12,00 \\
\hline $\mathrm{Y}$ & 18,40 & 1,90 & 10,10 & 28,10 & 6,20 & 5,80 \\
\hline $\mathrm{Ta}$ & 0,70 & 0,70 & 1,50 & 1,70 & 0,20 & 1,10 \\
\hline V & 215,00 & 59,00 & 210,00 & 229,00 & 532,00 & 274,00 \\
\hline Co & 1,10 & 9,00 & 29,00 & 3,00 & 6,00 & 4,00 \\
\hline $\mathrm{Cu}$ & 7,00 & 84,00 & 340,00 & 24,00 & 51,00 & 46,00 \\
\hline $\mathrm{Ni}$ & 5,00 & 50,00 & 181,00 & 14,00 & 18,00 & 15,00 \\
\hline $\mathrm{Zn}$ & 6.00 & 46,00 & 239,00 & 7,00 & 14,00 & 11,00 \\
\hline $\mathrm{Cr}$ & 1000.0 & 180,0 & 230,00 & 210,00 & 1540,00 & 640,00 \\
\hline $\mathrm{Sn}$ & 1,00 & 1,00 & 3,00 & 2,00 & 1,00 & 2,00 \\
\hline $\mathrm{Ga}$ & 3,60 & 8,30 & 25,50 & 21,20 & 14,80 & 23,90 \\
\hline $\mathrm{Au}$ & 0,03 & 2,28 & 0,04 & 0,04 & 0,02 & 0,02 \\
\hline $\mathrm{Sc}$ & 0,02 & 34,00 & 17,00 & 29,00 & 27,00 & 40,00 \\
\hline $\mathrm{Ag}$ & 0,28 & 0,50 & 0,06 & 0,07 & 0,75 & 0,03 \\
\hline $\mathrm{Th} / \mathrm{U}$ & 0,18 & 5,21 & 4,72 & 4,95 & 2,07 & 5,02 \\
\hline $\mathrm{Co} / \mathrm{Zn}$ & & 0,2 & 0,12 & 0,42 & 0,43 & 0,36 \\
\hline
\end{tabular}

\subsubsection{Rare Earths}

The sum of the REEs of the quartz vein is $50.30 \mathrm{ppm}$. The LREE/HREE and $(\mathrm{La} / \mathrm{Yb})_{\mathrm{N}}$ ratios of the quartz vein samples show values of 2.11 and 1.33 , respectively (Table 3 ). 
Table 3. Rare earth concentrations in ppm of Zom PE profile.

\begin{tabular}{|c|c|c|c|c|c|c|}
\hline & \multicolumn{4}{|c|}{ PE } & \multirow[b]{2}{*}{$\begin{array}{l}\text { Nodular } \\
\text { level }\end{array}$} & \multirow[b]{2}{*}{ Clay } \\
\hline & $\begin{array}{l}\text { Quartz } \\
\text { vein }\end{array}$ & $\begin{array}{l}\text { Coarse } \\
\text { saprolite }\end{array}$ & $\begin{array}{l}\text { Fine } \\
\text { saprolite }\end{array}$ & $\begin{array}{c}\text { Gravelly } \\
\text { level }\end{array}$ & & \\
\hline Colors & grey & $\begin{array}{l}\text { Saproilte } \\
\text { grey }\end{array}$ & $\begin{array}{l}\text { saproilte } \\
\text { red }\end{array}$ & $\begin{array}{l}\text { level } \\
\text { red }\end{array}$ & red & red \\
\hline Depth (m) & & 0,25 & 0,5 & 0,8 & 1 & 1 \\
\hline Samples (ppm) & $\mathrm{Z1}$ & Z2 & $\mathbf{Z 3}$ & $\mathbf{Z 4}$ & Z5 & Z6 \\
\hline $\mathrm{La}$ & 5,50 & 5,80 & 18,00 & 38,60 & 4,90 & 15,80 \\
\hline $\mathrm{Ce}$ & 7,10 & 6,80 & 47,90 & 65,60 & 26,10 & 35,00 \\
\hline $\operatorname{Pr}$ & 2.96 & 0,85 & 3,72 & 9,55 & 1,22 & 2,73 \\
\hline $\mathrm{Nd}$ & 13,30 & 2,50 & 12,90 & 37,40 & 4,60 & 9,30 \\
\hline $\mathrm{Sm}$ & 4,09 & 0,44 & 2,39 & 6,70 & 1,32 & 1,82 \\
\hline $\mathrm{Eu}$ & 1,19 & 0,10 & 0,52 & 1,48 & 0,39 & 0,46 \\
\hline $\mathrm{Gd}$ & 3,88 & 0,33 & 2,07 & 5,60 & 1,21 & 1,34 \\
\hline $\mathrm{Tb}$ & 0,77 & 0,05 & 0,31 & 0,88 & 0,26 & 0,20 \\
\hline Dy & 4,47 & 0,34 & 1,67 & 4,94 & 1,66 & 1,33 \\
\hline Ho & 0,88 & 0,06 & 0,34 & 1,05 & 0,33 & 0,23 \\
\hline $\mathrm{Er}$ & 2,57 & 0,27 & 1,24 & 3,04 & 1,04 & 0,83 \\
\hline $\mathrm{Tm}$ & 0,41 & 0,03 & 0,18 & 0,46 & 0,13 & 0,09 \\
\hline $\mathrm{Yb}$ & 2,81 & 0,35 & 1,31 & 3,14 & 1,21 & 0,92 \\
\hline $\mathrm{Lu}$ & 0,37 & 0,02 & 0,21 & 0,52 & 0,15 & 0,11 \\
\hline Y/Ho & 20,90 & 31,67 & 29,70 & 26,76 & 18,79 & 25,22 \\
\hline $\mathrm{Y} / \mathrm{P}_{2} \mathrm{O}_{5}$ & 1840,00 & 2,68 & 144,30 & 702,50 & 38,75 & 116,00 \\
\hline$\sum \mathrm{REE}$ & 50,30 & 17,94 & 92,76 & 178,96 & 44,52 & 70,16 \\
\hline$\sum$ LREE & 34,14 & 16,49 & 85,43 & 159,33 & 38,53 & 65,11 \\
\hline$\sum$ HREE & 16,16 & 1,45 & 7,33 & 19,63 & 5,99 & 5,05 \\
\hline LREE/HREE & 2,11 & 11,37 & 11,65 & 8,11 & 6,43 & 12,89 \\
\hline$(\mathrm{La} / \mathrm{Yb}) \mathrm{N}$ & 1,33 & 11,26 & 9,33 & 8,35 & 2,75 & 11,67 \\
\hline$(\mathrm{Ce} / \mathrm{Ce} *)$ & 3,98 & 1,03 & 10,31 & 16,90 & 6,77 & 6,29 \\
\hline$\left(\mathrm{Eu} / \mathrm{Eu}^{*}\right)$ & 3,73 & 0,25 & 1,48 & 4,08 & 1,18 & 1,12 \\
\hline
\end{tabular}

\subsection{Study of Heavy Minerals Accompanying Gold in the Weathering Materials}

The heavy minerals of the following particle size fractions: $0.315 \mathrm{~mm}, 0.250 \mathrm{~mm}, 0.160 \mathrm{~mm}$ and $0.08 \mathrm{~mm}$ of the heavy mineral concentrates of coarse saprolite, of the speckled or fine saprolite level and of the gravelly level of the PE profile were observed under a polarizing microscope. These studied heavy mineral concentrates contain both silicate minerals and non-silicate minerals.

\subsubsection{Heavy Silicate Minerals from Weathering Materials}

They are represented by: zircon, tourmaline, andalusite, green hornblende, hypersthene, garnet, beryl, topaz and epidote (Figure 5):

-Zircon: is found in all samples of gold levels in varying proportions. It presents as a bipyramidal prism. In LP, it's colorless and its pleochroism is zero. Its relief is very strong. In LPA, it presents a straight extinction and polarizes in the vivid colors of $2^{\text {nd }}$ and $3^{\text {rd }}$ order (Figure $5 \mathrm{~A}$ and $\mathrm{B}$ ).

-Tourmaline: Also found in all heavy mineral concentrate samples from weathering materials. It is presented in prismatic crystals with striated faces. In LP, it's brown to brown-black, its pleochroism is intense and reverse (brown following the North-South direction and dark brown following the East-West direction) and its relief is medium. In LPA, it shows a straight extinction and it polarizes in the vivid colors of the 2nd order (Figure 5C and D).

- Green hornblende: it is found only in the gravelly level of the eluvium. In LP, it is hexagonal (basal section) or elongated (longitudinal section). Its relief is average. In LPA, its extinction is oblique. It polarizes in vivid 1st order hues (Figure 5E and F).

-Andalusite: it is found in coarse saprolite and fine saprolite of materials in varying proportions. It is presented in the form of coarse prisms with irregular contours. In LP, it is colorless and its pleochroism is zero. Its relief is average. In LPA, 
its extinction is straight and it polarizes in the gray tints of the 1st order (Figure $5 \mathrm{G}$ and $\mathrm{H}$ ).

-Hypersthene: found in coarse saprolite and fine saprolite in eluviums. It comes in the form of prismatic crystals. In LP it is green-yellow to green-brown. The relief is strong and its pleochroism is weak. In LPA, its extinction is straight and polarizes in the vivid colors of the $1^{\text {st }}$ order (Figure $5 \mathrm{I}$ and $\mathrm{J}$ ).

-Garnets: is present in the coarse saprolite of weathering materials. It comes in the form of irregular rounded and cracked grains. In LP, it is colorless, a very strong relief. In LPA, it is off (Figure 5K and L).

-Beryl: In LP, it is pale green, its pleochroism is not very clear, its relief is weak. In LPA, it shows a straight extinction and it polarizes in the gray tints of the $1^{\text {st }}$ order. It is a mineral mainly found in granites and pegmatites as well as in hydrothermal veins (Figure 5M and $\mathrm{N}$ ).

-Topaz: occurs as bipyramidal crystals. In LP, it is colorless, its pleochroism is zero and its relief medium. In LPA, its extinction is right polarized in the gray tints of the $1^{\text {st }}$ order (Figure $5 \mathrm{O}$ and $\mathrm{P}$ ).

-Epidote: it comes in the form of a prism. It is light green and its pleochroism is weak. In LPA, she has two extinctions: straight and oblique. It polarizes in vivid $2^{\text {nd }}$ order hues (Figure 5Q and $\mathrm{R}$ ).

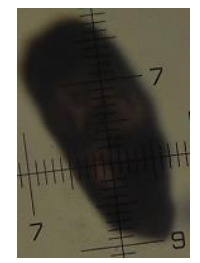

A : Zircon in LP

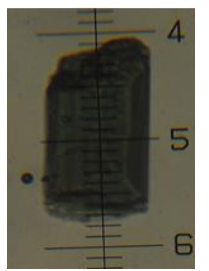

I : Hypersthene $\mathbf{J}$ : Hypersthene in LP

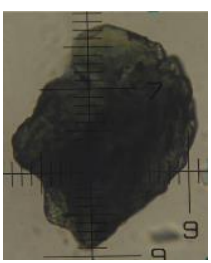

Q : Epidote in LP

B : Zircon in LPA

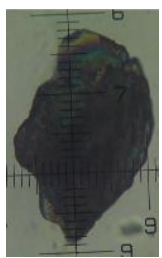

R : Epidote in LPA
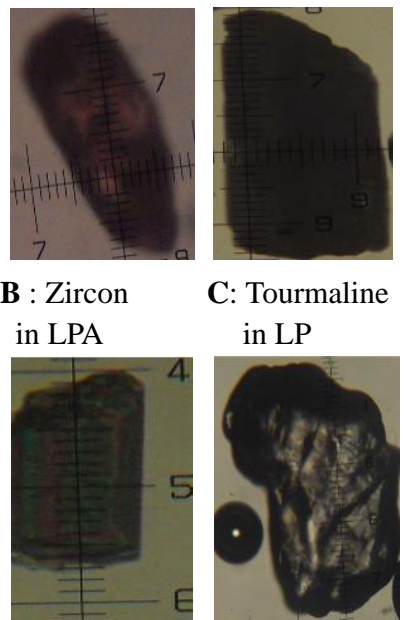

K : Garnet in LP

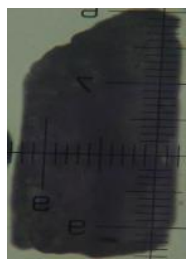

D : Tourmaline in LPA

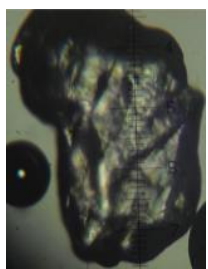

L : Garnet in LPA

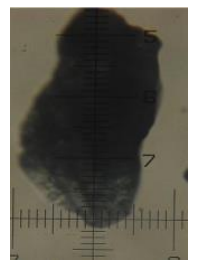

E : Green

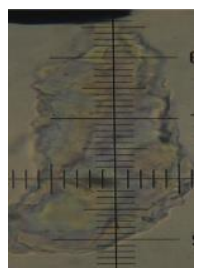

M : Beryl in LPA

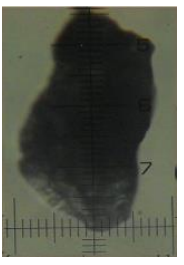

F : Green hornblende in LPA in LP

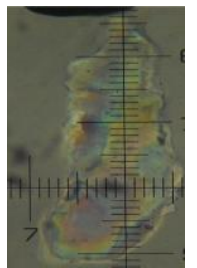

N : Beryl

in LPA

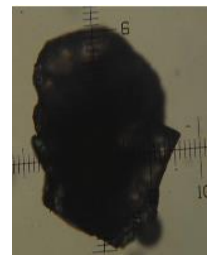

G : Andalusite

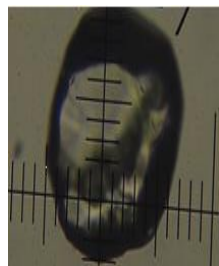

O : Topaz in LP

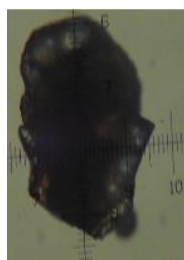

H : Andalusite in LPA

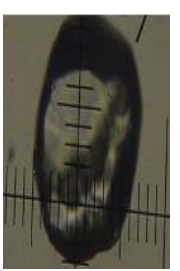

P : Topaz in LPA

Figure 5. Heavy silicate minerals from quartz vein weathering materials of Zom's PE profile

\subsubsection{Heavy Non-silicate Minerals from Weathering Materials}

The heavy non-silicate minerals in the concentrates are represented by: rutile, apatite, anatase and opaque oxides (Figure $6)$.

-Rutile: In LP, it is reddish brown. Its pleochroism is zero and its relief is strong. In LPA, its extinction is straight. Its birefringence is very strong (Figure 6A and B).

-Apatite: It is a non-silicate mineral found in the coarse and fine saprolite of eluvium. In LP, it is colorless or very weakly colored in blue, yellow. Its relief is average. It is non-pleochroic. In LPA, its extinction is straight and polarizes in the vivid colors of the 1st order (Figure 6C and D).

-Anatase: It is a polymorph of rutile and is found in the coarse and fine saprolite of weathering materials. In LP, it is transparent in clear crystals, its pleochroism is weak and its relief is strong. In LPA, its extinction is straight and polarizes in the vivid colors of the $3^{\text {rd }}$ order (Figure $6 \mathrm{E}$ and F). 
-Opaque oxides: These are sub-rounded, black grains that are always extinct in LP and LPA (Figure 6G).

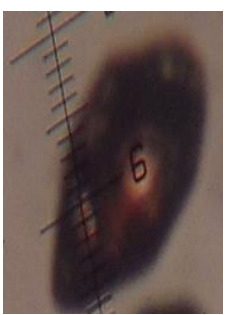

A: Rutile in LP

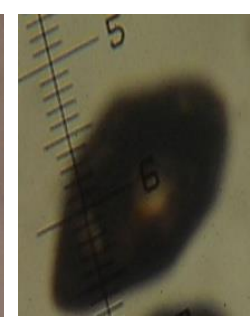

B : Rutile in LPA

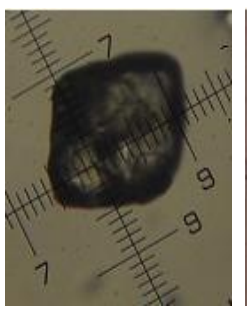

C : Apatite in LP

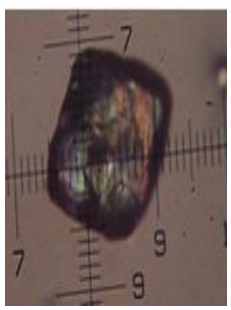

D : Apatite in LPA

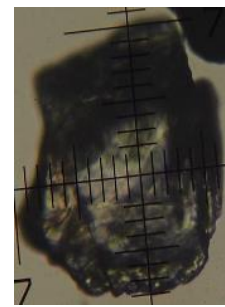

E : Anastase in LP

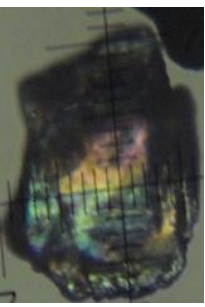

F : Anatase in LPA

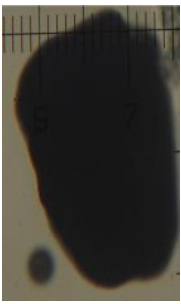

G : Opaque oxides

Figure 6. heavy non-silicate minerals from weathering material on the Zom profile quartz vein

In finally, all these minerals characterize a magmatic and metamorphic geological environment identical to that of the Congo craton (Toteu et al, 2006; Tchameni 1997; Ntep Gwet et al., 2010).

\subsection{Mineralogy of Weathering Materials by X-ray Difractometry}

$\mathrm{X}$-ray diffractograms obtained from powders of samples of Zom's PE profile alteration materials show that they consist of quartz (40.81-87.09\%), kaolinite (12.91-57.14\%), goethite (1.44-23.39\%) and hematite (0.11-1.27\%). Minerals such as hematite and goethite are not present in the Z2 coarse saprolite sample. Hematite is also absent in sample Z6 (Figure 7).

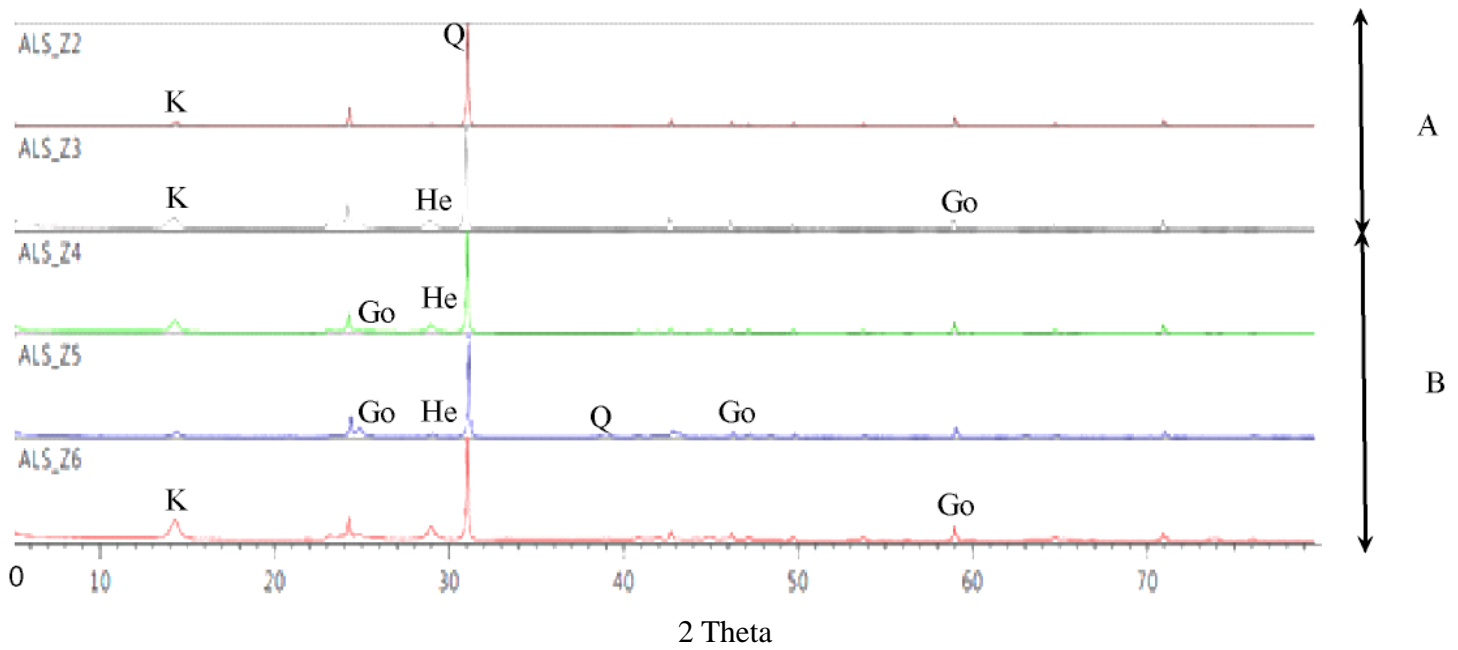

Figure 7. X-ray diffractograms of Zom's PE profile alteration material samples. Q : quartz ; K : kaolinite; Sm : smectite ; Go : goethite ; He : hematite

\subsection{Geochemistry of Gold Grains of the PE Profile of Zom}

The Electron Probe Micro Analysis (EPMA) is a technique that allows in situ and non-destructive analysis of all chemical elements from beryllium in a volume of the order of a cubic micrometer. The chemical composition of the gold particles is analyzed with an electron microprobe and the Au contents are measured on these particles. In total, ten (10) holes out of three (03) gold particles of the mineralized rock walls of the Zom PE profile were carried out by electron microprobe (Figure 8). These particles originate respectively from the coarse saprolite (Figure 8A), from the fine saprolite or speckled level (Figure 8B) and from the gravelly level (Figure 8C). These gold particles have been tested at specific points. It is observed that Mintom's gold consists essentially of $\mathrm{Au}(97.75 \%$ to $99.21 \%)$ with traces of $\mathrm{Ag}(0.02 \%$ to $0.16 \%)$, of $\mathrm{Bi}$ $(0.56 \%$ at $1.61 \%)$ and $\mathrm{Cu}(0.02 \%$ to $0.07 \%)$ (Table 4$)$. These Au contents are higher than those of the gold district of Bétaré Oya in eastern Cameroon (Akumbom et al., 2017) or those of Piéla, in Burkina Faso (Ouangrawa et al., 1996). Conversely, their $\mathrm{Ag}$ contents $(0.02$ to $0.16 \%)$ are lower. However, the presence of gold "pathfinders" such as: $\mathrm{Bi}, \mathrm{Mo}, \mathrm{Cu}$ and S implies a magmatic and hydrothermal context of the primary gold deposit (Guilbert and Park, 1986). 


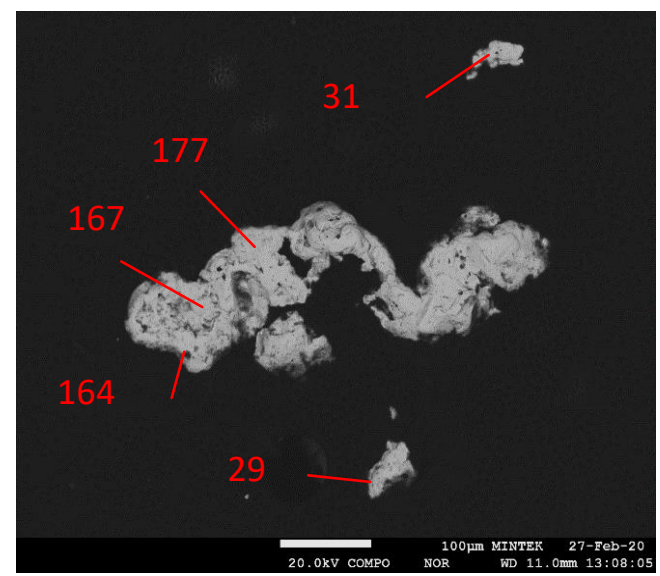

A

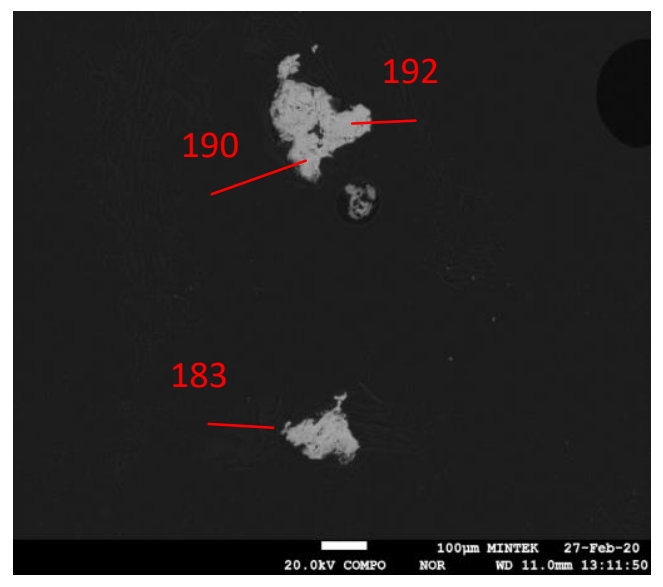

B

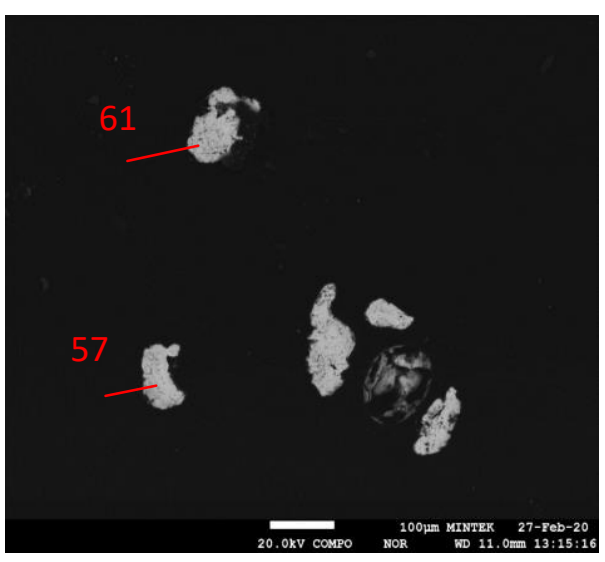

C

Figure 8. WDS images of gold particles of Zom quartz vein PE profile alteration materials. A : coarse saprolite from sample Z2 $(100 \mu \mathrm{m})$; B : fine saprolite from sample Z3 $(100 \mu \mathrm{m})$; C : gravelly level from sample Z4 (100 $\mu \mathrm{m})$

Table 4. Percentage by weight of the chemical elements of the gold particles of the Zom PE profile, after analysis with an electron microprobe (WDS)

\begin{tabular}{|c|c|c|c|c|c|c|c|c|c|c|c|c|c|c|c|}
\hline Position & $\mathrm{Ag}$ & As & $\mathrm{Au}$ & $\mathrm{Bi}$ & $\mathrm{Ce}$ & $\mathrm{Cu}$ & $\mathrm{Fe}$ & Mo & $\mathrm{Pt}$ & $\mathrm{S}$ & $\mathrm{Sb}$ & $\mathrm{Sn}$ & V & $\mathrm{Zn}$ & Total \\
\hline Position6_3_164 & 0,02 & - & 99,12 & 0,74 & 0,17 & 0,05 & - & 0,65 & - & - & 0,02 & - & - & - & 100,76 \\
\hline Position6_3_167 & 0,04 & - & 97,75 & 0,67 & 0,19 & 0,07 & 0,02 & 0,75 & - & - & - & - & - & - & 99,48 \\
\hline Position6_3_177 & 0,04 & - & 98,10 & 0,78 & 0,18 & 0,07 & 0,03 & 0,36 & - & 0,06 & - & - & - & - & 99,61 \\
\hline Position6_3-29 & 0,16 & - & 98,11 & 1,61 & - & - & - & - & - & 0,10 & - & - & 0,02 & - & 100,00 \\
\hline Position6_3-31 & 0,02 & - & 99,51 & 1,00 & - & 0,02 & 0,03 & - & - & - & - & - & - & - & 100,59 \\
\hline Position6_4_183 & 0,02 & - & 98,73 & 0,72 & 0,16 & 0,03 & 0,06 & 0,15 & - & - & - & - & - & 0,12 & 100,00 \\
\hline Position6_4_190 & 0,07 & - & 98,49 & 0,65 & 0,20 & 0,07 & 0,03 & 0,62 & 0,02 & - & - & - & - & 0,09 & 100,25 \\
\hline Position6_4_192 & 0,05 & - & 98,24 & 0,56 & 0,15 & 0,06 & 0,06 & 0,38 & - & - & - & 0,06 & - & 0,25 & 99,81 \\
\hline Position6_5-57 & 0,06 & - & 98,59 & 1,02 & - & - & 0,03 & - & - & 0,06 & - & - & 0,09 & - & 99,85 \\
\hline Position6_5-61 & 0,02 & - & 99,21 & 1,24 & - & - & 0,03 & - & - & 0,05 & - & - & - & - & 100,55 \\
\hline DL & 0,01 & 0,08 & 0,05 & 0,03 & 0,04 & 0,02 & 0,02 & 0,06 & 0,02 & 0,03 & 0,01 & 0,02 & 0,02 & 0,02 & \\
\hline
\end{tabular}

DL $=$ Detection Limits 


\subsection{Identification and Behavior of Gold with Accompanying Chemical Elements of Gold in Weathering Materials}

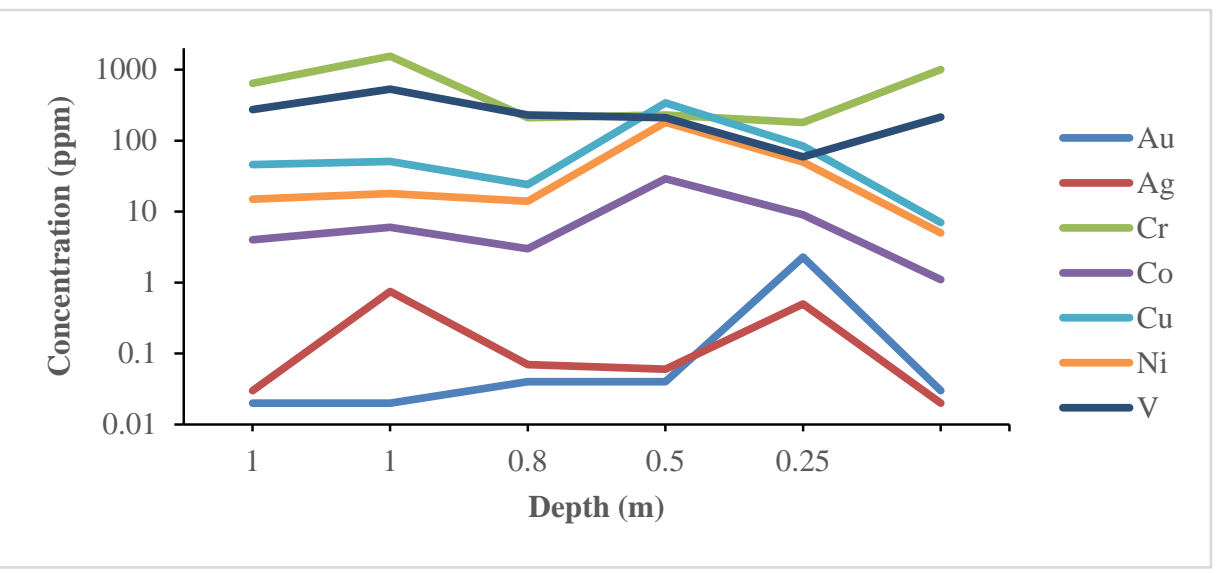

Figure 9. Diagram of the chemical elements accompanying gold in the PE profile

Analysis of the diagram above shows that almost all the transition elements $(\mathrm{Cr}, \mathrm{Co}, \mathrm{Cu}, \mathrm{Ni}, \mathrm{V}$ and $\mathrm{Ag})$ exhibit overall similar behavior with respect to gold (Figure 9), due to of their high density $\geq 3.2$ like that of gold, particularly Ag whose behavior is very similar and identical to that of gold. These behaviors would testify to the identical origin of all these elements (Corin, 1931; Boyle, 1979; Dejonghe, 2000; Yannick Bruni, 2017).

\subsection{Geochemistry of Alteration Materials of the Studied Profile}

\subsubsection{The Major Elements}

Saprolite is characterized by high contents of $\mathrm{SiO}_{2}(9.02-61.80 \%), \mathrm{Fe}_{2} \mathrm{O}_{3}(9.92-75.70 \%), \mathrm{TiO}_{2}(0.22-1.13 \%)$. It shows moderate concentrations of $\mathrm{Al}_{2} \mathrm{O}_{3}$ (3.78-18.25\%) (Table 1). The concentrations of $\mathrm{MnO}, \mathrm{MgO}, \mathrm{K}_{2} \mathrm{O}$ and $\mathrm{P}_{2} \mathrm{O}_{5}$ are slightly increasing compared to the rock, while those of $\mathrm{CaO}$ and $\mathrm{Na}_{2} \mathrm{O}$ are constant and less than $1 \%$. The LOI and CIA values vary respectively from 9.62 to 11.70 and from 98.86 to $99.21 \%$. These values justify at will the intense and complete deterioration of the materials and the presence of hydrated minerals. The value of the $\mathrm{SiO}_{2} / \mathrm{Al}_{2} \mathrm{O}_{3}$ ratio is less than 5 and that of the $\mathrm{K}_{2} \mathrm{O} / \mathrm{Na}_{2} \mathrm{O}$ ratio varies from 1 to $19 \%$ (Table 1). These reports show that these materials are rich in silica. The glebular level or horizon of accumulation shows high concentrations of $\mathrm{SiO}_{2}(52.90-72.60 \%)$ and moderate contents of $\mathrm{Al}_{2} \mathrm{O}_{3}(8.83-17.55 \%)$ and low of $\mathrm{TiO}_{2}(0.41-1,27 \%)$. The $\mathrm{Fe}_{2} \mathrm{O}_{3}$ concentrations are decreasing (7-29.90\%). The concentrations of the other oxides are moderate (Table 1).

\subsubsection{Traces Elements}

Saprolite is characterized by an enrichment in LILE relative to the rock. HFSEs generally show increasing concentrations with respect to rock, with the exception of $\mathrm{U}(0.38-3.26 \mathrm{ppm}), \mathrm{Y}(1.90 \mathrm{ppm})$ in sample $\mathrm{Z} 3$ whose concentrations decrease and impoverish compared to rock. TTEs generally show increasing concentrations, with the exception of $\mathrm{V}, \mathrm{Cr}$ and $\mathrm{Ag}$ where depletion is observed in sample Z3 respectively (59ppm), (180ppm) and (0.06ppm) (Table 2). The concentrations of LILE at the glebular level show an enrichment compared to rock and saprolite. HFSEs also show the same behavior except for Y and Ta where depletion is observed in samples Z5 (6.20ppm), Z6 (5.80ppm) and Z5 (0.20ppm) respectively. The TTEs show an enrichment with respect to the rock and the saprolite, except for Au which presents an impoverishment in the Z5 and Z6 materials with a value of $0.02 \mathrm{ppm}$. Silver (Ag) shows a higher concentration in sample Z5 from the glebular level compared to Z4 and Z6 which are also higher than the Ag concentrations contained in rock and saprolite (Table 2). The trace element spectra of weathering materials normalized to chondrites (McDonough and Sun, 1995) are shown in Figure 10. These spectra show almost similar behavior for all types of materials. Figure 10 shows an enrichment in LILE, with the exception of $\mathrm{Rb}$ and $\mathrm{Sr}$ which show depletion respectively in the materials Z2, Z5 and Z2. HFSE elements show enrichment compared to chondrites. Most transition metals (TTEs) show depletion compared to chondrites. However, some metals show enrichment such as V and Ga on all materials, $\mathrm{Cu}$ in sample Z3, Sn in samples Z2, Z3 and Z6, $\mathrm{Au}$ in sample Z2 and Ag in samples Z2 and Z5. 


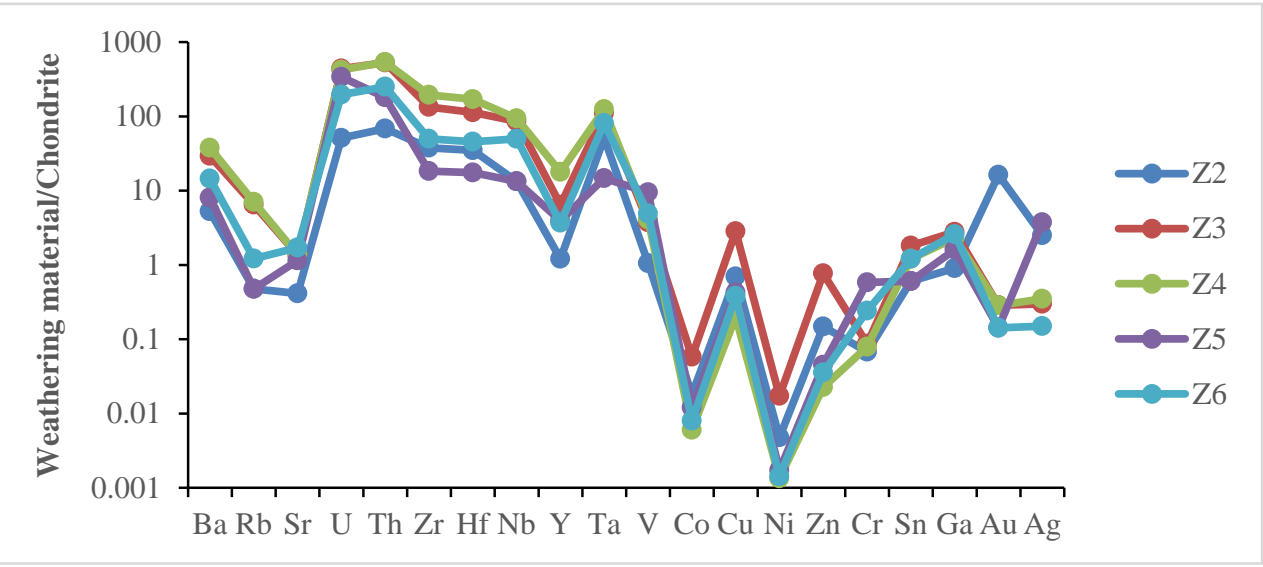

Figure 10. Normalization spectra of the trace elements of the alteration materials of the Zom PE profile from the chondrite values of Mc Donough et Sun (1995)

\subsubsection{Rare Earths}

In saprolite, the sum of REEs varies between 17.94 and $92.76 \mathrm{ppm}$, with a depletion of HREE compared to LREEs (Table 3). The geochemical data of the clayey level show a sum of the REEs varying from 44.52 to $178.96 \mathrm{ppm}$. The LREEs show an enrichment compared to the HREEs. Figures 11 and 12 shows the rare earths spectra of weathering materials normalized to the values of chondrites (McDonough and Sun, 1995) and rock, respectively. The spectra of the REEs of all materials show an enrichment in LREE compared to HREE (Figure 11). Figure 12 shows the REE spectrum of weathering materials normalized to the quartz vein. These spectra show that the Z4 sample is enriched in REE relative to the rock. However, the rest of the samples show depletion.

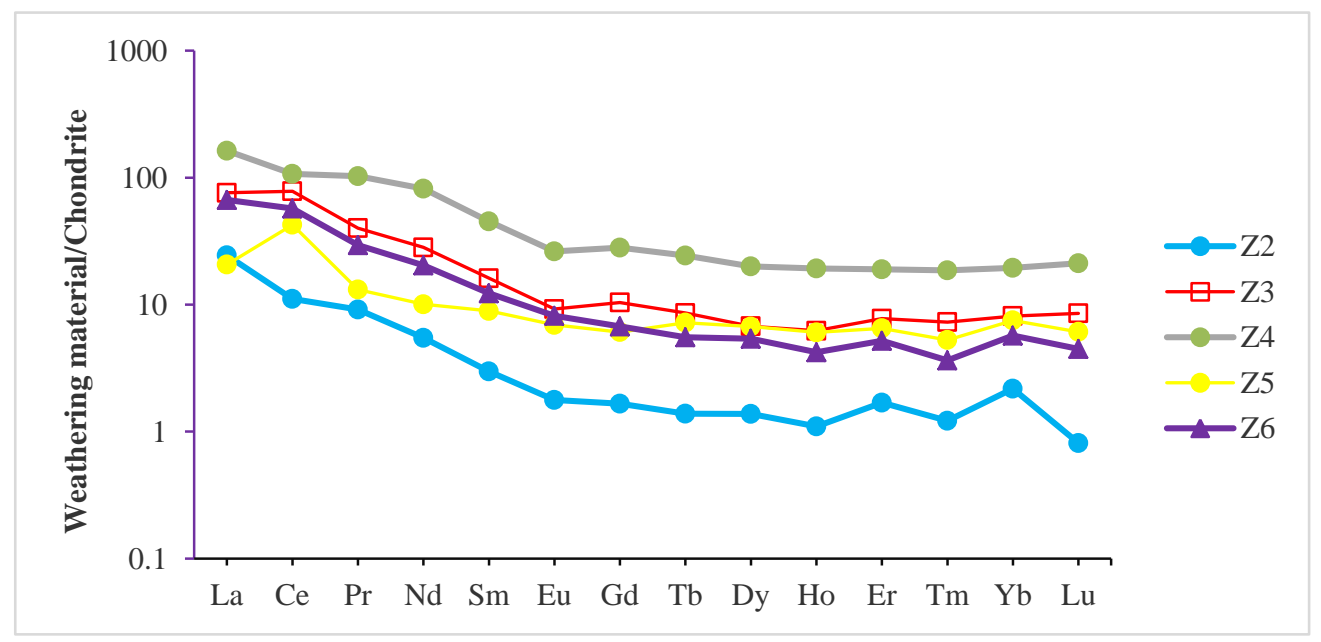

Figure 11. Rare earth normalization spectra of Zom PE profile alteration materials from Mc Donough and Sun chondrite values (1995) 


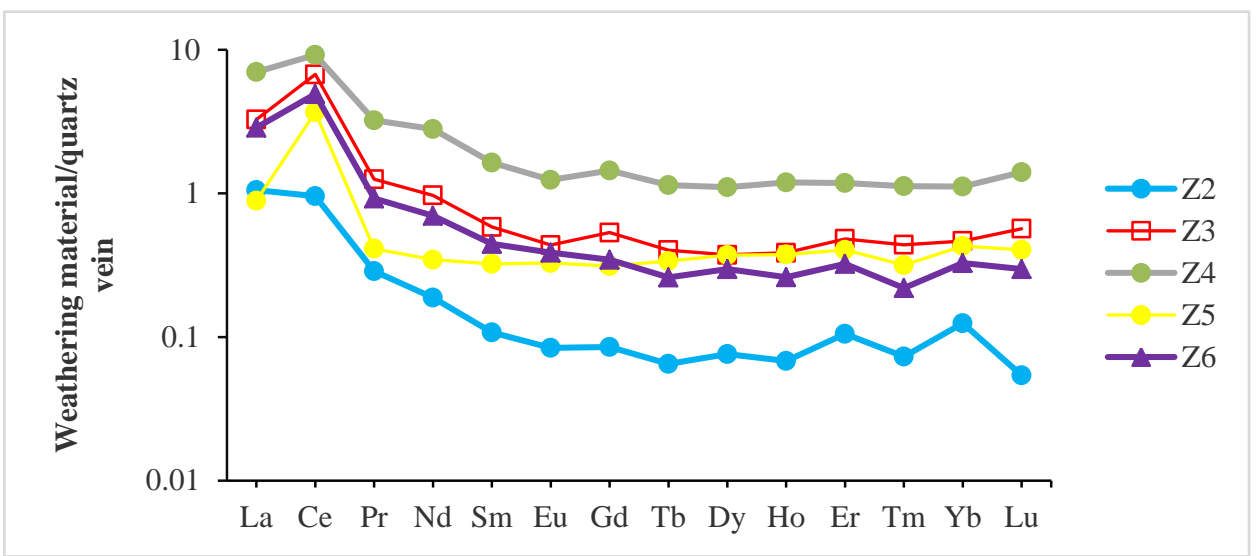

Figure 12. Rare earth normalization spectra of alteration materials of Zom's PE profile versus quartz vein

\section{Hydrothermal Alteration}

The presence and abundance of certain heavy minerals such as epidote, beryl, topaz, tourmaline and zircon justify the hydrothermal aspect in the zone favorable to magmatic processes, which allowed the formation of these gold mineralizations. The alteration of the quartz vein by bioclimatic processes has made it possible to highlight and significantly clay minerals such as smectite and kaolinite of type $2 / 1$ and $1 / 1$, respectively, thus reflecting hydrothermal phenomena such as bisiallitization and monosialitization. These mineralogical characteristics justify the presence of hydrothermalism and metasomatic processes at the origin of the deposit of gold in the Mintom zone.

\section{Conclusion}

The results obtained in this study show that the quartz veins hosted in the granites are the petrographic facies at the origin of the establishment of gold. These facies have undergone magmatic processes, in particular the intrusion of hydrothermal fluids due to tectonic events. The migration of gold from the rock to the upper levels accompanied by a mineral association (beryl, epidote, zircon, topaz and tourmaline) is characteristic of the decay and weathering that affected the underlying rock.

\section{Acknowledgments}

The authors thank all the staff of the SGS laboratory in Johannesbourg in South Africa, the Institute for Development Research in France and the Australian Laboratory Services Minerals in Johannesbourg also located in South Africa, for the microprobe analyzes, mineralogical and chemical.

\section{References}

Andrade, W. O., Machesky, M. L., \& Rose, A. W. (1991). Gold distribution and mobility in the surficial environment, Carajas region, Brazil. J. Geochem. Explor, 40, 95-114. https:// doi.org/10.1016/0375-6742(91)90033-Q

Al, T. A., Leybourne, M. I., Maprani, A. C., Macquarrie, K. T., Dalziel, J. A., Fox, D., \& Yeats, P. A. (2006). Effects of acid-sulfate weathering and cyanide-containing gold tailings on the transport and fate of mercury and other metals in Gossan Creek: Murray Brook mine, New Brunswick, Canada. Appl. Geochem, 21, 1969-1985.

Akwinga A.V. (2010). Lode gold mineralization in the Neoproterozoic granitoids of Batouri, Southeastern Cameroon. Doctorate Thesis. p. 202.

Aleksandrov, S. M. (2007). Gold behavior during endogenic and supergene alterations of sulfides in Magnesian Skarns. Geochem. Int., 45, 152-169.

Baker, W. E. (1978). The role of humic acid in the transport of gold. Geochim. Cosmochim. Acta, 42, 645-649. https://doi.org/10.1016/0016-7037(78)90009-1

Benedetti, M., \& Boulègue, J. (1991). Mechanism of gold transfer and deposition in a supergene environment. Geochim. Cosmochim. Acta, 55, 1539-1547. https:// doi.org/10.1016/0016-7037(91)90126-P

Bowell, R. J. (1992). Supergene gold mineralogy at Ashanti, Ghana: implications for the supergene behavior of gold. Mineral. Mag., 56, 545-560. https://doi.org/10.1180/minmag.1992.056.385.10

Bowell, R. J., Foster, R. P., \& Gize, A. P. (1993b). The mobility of gold in tropical rain forest soils. Econ. Geol., 88, 
999-1016. https:// doi.org/10.2113/gsecongeo.88.5.999

Bowell, R. J., Gize, A. P., \& Foster, R. P. (1993a). The role of fulvic acid in the supergene migration of gold in tropical rain forest soils. Geochim. Cosmochim. Acta, 57, 4179-4190. https://doi.org/10.1016/0016-7037(93)90314-M

Burnham, O. M., \& Schweyer, J. (2004). Trace element analysis of geological samples by inductively coupled plasma-mass spectrometry at the Geoscience Laboratories: revised capacities due to improvements to instrumentation. Ontario Geological Survey, Open file Report 6145, 54, 1-20.

Colin, F., Sanfo, Z., Bourlès, E. B. D., \& Minko, A. E. (1997). Gold: a tracer of the dynamics of tropical laterites. Geology, 25, 81-84. https://doi.org/10.1130/0091-7613(1997)025<0081:GATOTD>2.3.CO;2

Colin, F., \& Vieillard, P. (1991). Behavior of gold in the lateritic equatorial environment: weathering and surface dispersion of residual gold particles, at Dondo Moli, Gabon. Appl. Geochem., 6, 279-290. http://dx.doi.org/10.1016/0833-2927(91)90005-A

Colin, F. (1992). Gold tracer of the chemical history of the lateritic alterosphere under equatorial forest. Authorization to supervise research. Thesis, University of Aix-Marseille III, France, p. 171.

Colin, F., Vieillard, P., \& Ambrosi, J. P. (1993). Quantitative approach to physical and chemical gold mobility in equatorial rainforest lateritic environment. Earth Planet. Sci. Lett., 114, 269-285. https://doi.org/10.1016/0012-821X(93)90030-D

Dold, B., \& Fontboté, L. (2002). A mineralogical and geochemical study of element mobility in sulfide mine tailings of $\mathrm{Fe}$ oxide $\mathrm{Cu}-\mathrm{Au}$ deposits from the Punta del Cobre belt, northen Chile. Chem. Geol., 189, 135-163. https://doi.org/10.1016/S0009-2541(02)00044-X

Edou-Minko, A. (1989). Petrology and geochemistry of the 'stone-line' laterites of the Ovala gold deposit. Application to prospecting in a humid equatorial zone (Gabon). Thesis, University of Poitiers, France. p. 147.

Edou-Minko, A., Colin, F., Lecomte, P., \& Trescases, J. J. (1992). Lateritic alteration of the Ovala gold deposit (Gabon) and formation of a superficial dispersion anomaly. Mineralium Deposita, 25, 90-100.

Freyssinet, Ph., Zeegers, H., \& Tardy, Y. (1989). Morphology and geochemistry of gold grains in lateritic profiles of southern Mali. J. Geochem. Explor., 32, 17-31. https://doi.org/10.1016/0375-6742(89)90041-1

Fairbrother, L., Brugger, J., Shapter, J., Laird, J. S., Southam, G., \& Reith, F. (2012). Supergene gold transformation: biogenic secondary and nano-particulate gold from arid Australia. Chem. Geol., 320-321, 17-31. https://doi.org/10.1016/j.chemgeo.2012.05.025

Gong, Q. J., Deng, J., Wang, C. M., Wang, Z. L., \& Zhou, L. Z. (2013). Element behaviors due to rock weathering and its implication to geochemical anomaly recognition: a case study on Linglong biotite granite in Jiaodong peninsula, China. J. Geochem. Explor., 128, 14-24. https://dx.doi.org/10.1016/j.gexplo.2013.01.004

Gazel, J., Hourcq, V., \& Nikclès, M. (1956). Geological map of Cameroon at 1: 1,000,000: explanatory note. Paris: Department of Mines and Geology of Cameroon. Bulletin of the Department of Mines and Geology.

Hough, R. M., Noble, R. R. P., \& Reich, M. (2011). Natural gold nanoparticles. Ore Geol. Rev., 42, $55-61$. https://doi.org/10.1016/j.oregeorev.2011.07.003

Kalinin, Y. A., Kovalev, K. R., Naumov, E. A., \& Kirillov, M. V. (2009). Gold in the weathering crust at the Suzdal' deposit (Kazakhstan). Russ. Geol. Geophys., 50, 174-187. https://doi.org/10.1016/j.rgg.2008.09.002

Leybourne, M. I., Goodfellow, W. D., Boyle, D. R., \& Hall, G. E. M. (2000). Form and distribution of gold mobilized into surface waters and sediments from a gossan tailings pile, Murray Brook massive sulphide deposit, New Brunswick, Canada. Appl. Geochem., 15, 629-646. https://doi.org/10.1016/j.oregeorev.2021.104033

Mann, A. W. (1984). Mobility of gold and silver in lateritic weathering profiles: some observations from Western Australia. Econ. Geol., 79(1), 38-49. http://dx.doi.org/10.2113/gsecongeo.79.1.38

McDonough, W. F., \& Sun, S. (1995). The composition of the earth. Chemical Geology, 120(3-4), 223-253. http://dx.doi.org/10.1016/0009-2541(94)00140-4

Myagkaya, I. N., Lazareva, E. V., Gustaytis, M. A., \& Zhmodik, S. M. (2016a). Gold and silver in a system of sulfide tailings. Part 1: migration in water flow. J. Geochem. Explor., 160, 16-30. https://dx.doi.org/10.1016/j.gexplo.2015.10.004

Myagkaya, I. N., Lazareva, E. V., Gustaytis, M. A., \& Zhmodik, S. M. (2016b). Gold and silver in a system of sulfide tailings. Part 2: reprecipitation on natural peat. J. Geochem. Explor., 165, 8-22. https://dx.doi.org/10.1016/j.gexplo.2016.01.016 
Mbenoun, M. A., Ngon Ngon, G. F., Bayiga, E. C., \& Yongue-Fouateu, R. (2013). Gold Behavior in Weathering Products of Quartz Vein in Mintom Area South Cameroon (Central Africa). International Journal of Geosciences, 4(10), 11. https://doi.org/10.4236/ijg.2013.410137

Ntep, G. P., Dupuy, J. J., Matip, O., Fombutu, F. A., \& Kalngui, E. (2001). Ressources Minérales du Cameroun. Notice explicative de la carte thématique des ressources minérales sur un fond géologique. MINEE. p. 373.

Oliveira, S. M. B. D., \& Oliveira, N. M. D. (2000). The morphology of gold grains associated with oxidation of sulphide-bearing quartz veins at São Bartolomeu, Central Brazil. J. S. Am. Earth Sci., 13, 217-224. https://doi.org/10.1016/S0895-9811(00)00021-3

Stoffregen, R. (1986). Observations on the behavior of gold during supergene oxidation at Summitville, Colorado, U.S.A., and implications for electrum stability in the weathering environment. Appl. Geochem., 1, 549-558. https://doi.org/10.1016/0883-2927(86)90062-4

Shuster, J., Lengke, M., Márquez-Zavalía, M. F., \& Southam, G. (2016). Floating gold grains and nanoparticles produced from the biogeochemical weathering of a gold-bearing ore. Econ. Geol., 111, 1485-1494. https://doi.org/10.2113/econgeo.111.6.1485

Tehna, N., Elisé, S., Ekoa, B. A. Z., \& Etame, J. (2019). Mine waste and heavy metal pollution in Bétaré-Oya Mining Area (Eastern Cameroon). Research Journal of Environmental and Earth Sciences, 6(4), 167-176.

Varajão, C. A. C., Colin, F., Vieillard, P., Melfi, A. J., \& Nahon, D. (2000). Early weathering of palladium gold under lateritic conditions, Maquiné mine, Minas Gerais, Brazil. Appl. Geochem., 15, 245-263.

Webster, J. G., \& Mann, A. W. (1984). The influence of climate, geomorphology and primary geology on the supergene migration of gold and silver. J. Geochem. Explor., 22, 21-42. http://dx.doi.org/10.1016/0375-6742 (84)90004-9

Yesares, L., Aiglsperger, T., Sáez, R., Almodóvar, G. R., Nieto, J. M., Proenza, J. A., Gómez, C., \& Escobar, J. M. (2015). Gold behavior in supergene profiles under changing redox conditions: the example of the Las Cruces deposit, Iberian pyrite belt. Econ. Geol., 110, 2109-2126.

\section{Copyrights}

Copyright for this article is retained by the author(s), with first publication rights granted to the journal.

This is an open-access article distributed under the terms and conditions of the Creative Commons Attribution license (http://creativecommons.org/licenses/by/4.0/). 